\title{
Calling Customer Role of Intent Repeat Order Partners Home Food Kita Perm BULOG Southeast Sulawesi Regional Office
}

\author{
Anggraeni Damayanti Salam ${ }^{1}$, Haedar Akib ${ }^{2}$, Aris Baharuddin ${ }^{3}$ \\ Program Studi Ilmu Administrasi Bisnis, Fakultas Ilmu Sosial, Universitas Negeri \\ Makassar \\ Email: Anggraenidamayanti.ad@gmail.com ${ }^{1}$, haedar652002@yahoo.com.au² Arisbaharuddin@yahoo.com ${ }^{3}$
}

\begin{abstract}
This study aims to determine the role of calling customer on the intention to repeat order of our food house partners perm BULOG Southeast Sulawesi Regional Office. This study uses a quantitative approach, a descriptive research type, with a research population of 304 partners and a sample of 75 partners. Data collection techniques used are through observation, questionnaires (questionnaires), and documentation. The data that has been obtained from the research results are processed using data analysis and using the SPSS.20 software application which consists of descriptive analysis techniques and inferential statistical analysis. The research results show that the role of calling customers for our food house partners perm BULOG Southeast Sulawesi Regional Office is in the category satisfactory with a percentage level of 61.4 percent, and for the intention of repeating orders for our home food partners perm BULOG Southeast Sulawesi Regional Office is in the high category with a percentage of 57.7 percent based on these data, the level of relationship is in the very strong category. It can be concluded that there is a positive and significant effect on the role of calling customer on the intention to repeat orders for our food house partners, perm BULOG, Southeast Sulawesi Regional Office.
\end{abstract}

Keywords: Customer Calling \& Intention to Repeat Order.

\section{INTRODUCTION}

BULOG is a state-owned public company engaged in food logistics. The scope of business of this state-owned company includes logistics / warehousing, surveying and eradicating pests, providing plastic sacks, transportation business, food commodity trading and retail business. As a company that continues to carry out public duties from the government, BULOG continues to carry out activities to maintain the Basic Purchase Price (HDP) for unhulled rice, stabilize prices, especially the basic price, distribute rice to the poor (Raskin) and manage food stocks. The main task of BULOG is to carry out Government duties in the field of logistics management through supply management, distribution and control of rice prices (maintaining Government Purchase Prices-HPP), as well as logistics services in accordance with applicable laws and regulations. The direction of change was getting stronger with the issuance of Keppres No. 166 of 2000, which was subsequently changed to Keppres No. 103/2000.

The strategy of perm BULOG in distributing its products is to build a new distribution network to achieve the targets set by perm BULOG. This network development program is called the Food House Kita program. Food House Kita or abbreviated (RPK) is a small community-owned outlet that sells a variety of food products or often referred to as staple foods such as rice, oil, sugar, chilies, eggs, and other staple goods. Food House Kita is a marketing network for Perum BULOG that aims to generate small people's businesses and for food services reached 1018 our Food Home network (Perum BULOG KanWil SulTra, 2020). Seeing the condition of the increase in the number of our food houses, which currently have reached 1018, of course, it will increase the amount of cash sales to our food houses in Southeast Sulawesi.Perum Bulog, Southeast Sulawesi Regional Office, currently has a total of 1018 RPK partners in Southeast Sulawesi and 304 specifically in Kendari City. Of the 304 RPK partners in Kendari city, 70\% of RPK partners are actively placing orders for 
112 |Jurnal Office: Jurnal Pemikiran Ilmiah dan Pendidikan Administrasi Perkantoran

Vol. 6 No. 2, July - December 2020. Page 111-116

commodities at the Perum Bulog Southeast Sulawesi Regional Office and the remaining 30\% RPK partners do not reorder.

Table 1.

Percentage of Annual Repeat Orders of Partners of RPK Perum BULOG Regional Office of SulTra

\begin{tabular}{cccc}
\hline Number & $\begin{array}{c}\text { Commodity } \\
\text { Sales } \\
\text { (Year) }\end{array}$ & Partners & $\begin{array}{c}\text { Percentage Repeat Order } \\
(\mathbf{\%})\end{array}$ \\
\hline 1 & 2017 & $>100$ & 40 \\
2 & 2018 & $>300$ & 68 \\
3 & 2019 & $>600$ & 82 \\
4 & 2020 & $>1000$ & 70 \\
\hline
\end{tabular}

Source: Commercial Sector of Perum BULOG, Southeast Sulawesi Regional Office

Based on the data table above, which is obtained directly from the commercial sector of the Regional Office of BULOG, Southeast Sulawesi Regional Office, it is known that at the beginning of the year the partners of Food House Kita were formed, there were more than 100 partners and obtained a percentage of partners' Repeat Orders of $40 \%$, this was due to Food House Kita partners who registered is still small, so the opportunity to do repeat orders is weak. In the second year in 2018 there were more than 300 partners registered and the percentage of partner repeat orders was $68 \%$, which was quite an increase from the first year. In the third year, more than 600 partners were registered with a percentage of partner repeat orders of 82\%. In 2019 the Southeast Sulawesi BULOG Public Corporation achieved the award because it managed to achieve the highest sales level of the BULOG in Sulawesi. In 2020 there are currently more than 1000 registered partners with a $70 \%$ percentage of partner repeat orders, a significant decline from the previous year. This is due to the increasing number of Food House Kita partners which make partners' opportunities to do repeat orders decrease due to the Out Of Stock or Commodity inventory has been sold out, making partners feel not served well and as a result, partners become bored waiting for commodities to return available.

Perum BULOG has provided relief to Food House Kita partners by implementing a Cash and Non-Cash Sales System with a very simple solution, from recording sales to our Food House to storing data related to the sales process to submitting sales reports to the center. The pillars of economic conditions that contribute to the economy at various levels (Guo et al., 2020; Purba, 2012; Purnasari \& Yuliando, 2015; Zhu et al., 2016), it is necessary to evaluate the achievement of markets served in accordance with the environment (Henni Zainal et al., 2018; Safarnia et al., 2011; Vijande et al., 2005).

Researchers continue to try to find information on why this happens so that there is a result that the Southeast Sulawesi Regional Office of BULOG rarely conducts Visit Customers or meets directly with partners, causing weak partner repeat order intentions. In solving this problem, the Southeast Sulawesi Regional Office of BULOG has certainly carried out a strategy that aims to develop RPK partnership services and mobilize all employees and personnel in it to provide the best service, especially with customer calling services. This strategy is carried out by contacting the registered RPK partners. The fascination of customer calling is very important in attracting repeat order partners (Deng et al., 2018; Herdiyanti et al., 2017; Kamrath et al., 2019; Lv et al., 2018; Peter et al., 1999). In this study, compilers will test the correctness of the strategy carried out by Perm BULOG Southeast Sulawesi Regional Office. 


\section{METHOD}

This research design uses a quantitative method approach. This research approach is carried out by processing all the data from the research location. The quantitative approach focuses more on finding data from the reality field and refers to evidence of concepts and theories that have been used. The type in this research is descriptive research. According to (Sugiyono, 2017) descriptive research is research conducted to find out the value of the independent variable, whether one or more (independent) variables without making comparisons or connecting between one variable and another. In this study consisted of 2 variables, namely variable $\mathrm{X}$ (Calling Customer) and variable $\mathrm{Y}$ (Repeat Order). These two variables aim to determine the role of Calling Customer in the intention of partner's Repeat Order. The study population was 304 partners and the sample in this study was 75 partners. Data collection techniques used are through observation, questionnaires (questionnaires), and documentation. The data that has been obtained from the research results are processed using data analysis and using the SPSS.20 software application which consists of validity $\&$ reality tests, descriptive analysis techniques and inferential statistical analysis..

\section{RESULTS AND DISCUSSION}

Description of the data in this study is to provide an overview or explanation of the research that has been carried out in the field. To get data about the subject of research, researchers used an instrument in the form of a questionnaire. Questionnaire consisting of 22 items in the form of questions with five alternative answers. With the details of the number of questions for the calling customer variable (X), there are 12 items and 10 questions for the Repeat order variable (Y). The questionnaire with 22 items was recapitulated or tabulated to determine the value of the questionnaire based on the frequency of respondents 'answers and the percentage of respondents' answers to each question. The research questionnaires were distributed to 75 respondents, namely partners of the Food House Kita Perm BULOG Southeast Sulawesi regional office who had been selected as the research sample.

\section{Description of Calling Customer Variables}

Descriptions of data to determine the role of Calling Customer were obtained by using a total of 12 questionnaire answers from respondents.

Table 2.

Distribution of Customer Calling Variables

\begin{tabular}{c|c|c|c}
\hline Interval & Category & Frequency & Percentage (\%) \\
\hline $12-21$ & Very Unsatisfactory & 0 & 0 \\
$22-31$ & Less satisfactory & 0 & 0 \\
$32-41$ & Good enough & 4 & 5,3 \\
$42-51$ & satisfy & 46 & 61,4 \\
$52-60$ & Very satisfy & 25 & 33,3 \\
Total & & 75 & 100 \\
\hline
\end{tabular}

Source: Results of Statistical Analysis through the SPSS Program. 20

From the results of the calculation of the data above, it can be seen based on the respondent's answer that the role of Calling Customer Perm BULOG Southeast Sulawesi Regional Office is classified as "Satisfactory" with a frequency of 46 respondents and a percentage level of $61.4 \%$. This can also be proven by finding the number of means and standard deviation as follows. 
114 |Jurnal Office: Jurnal Pemikiran Ilmiah dan Pendidikan Administrasi Perkantoran

Vol. 6 No. 2, July - December 2020. Page 111-116

Table 3

Summary of Analysis Results of Average and Standard Deviation of Variables

Calling Customer

Statistics

\begin{tabular}{|l|r|}
\hline XTotal $\quad$ Valid & 75 \\
Mean $\quad$ Missing & 0 \\
Std. Error of Mean & 49.69 \\
Median & .659 \\
Std. Deviation & 49.00 \\
\hline
\end{tabular}

Source: Results of Statistical Analysis through the SPSS Program. 20

Based on the analysis of the average and standard deviation of the calling customer variable in the table above, it shows that the mean (mean) score of respondents' answers is 49.69 and when consulted with the standard deviation based on the description table of calling customer variables above, then the average 49.69 are in the "Satisfactory" category interval, while the standard deviation is 5.70. The data was obtained from the results of data processing through the SPSS 20 program.

\section{Description of Repeat Order Variables}

Description of data to determine the level of intention to repeat order partners Food House Kita Perum BULOG Southeast Sulawesi Regional Office obtained to be done by using a total of 10 questionnaire answers from respondents.

Table 4.

Distribution of Repeat Order Variables

\begin{tabular}{c|c|c|c}
\hline Interval & Category & Frequency & Percentage (\%) \\
\hline $10-17$ & Very low & 0 & 0 \\
$18-25$ & Low & 1 & 1,3 \\
$26-33$ & High enough & 4 & 5,3 \\
$34-41$ & High & 43 & 57,5 \\
$42-50$ & Very high & 27 & 35,9 \\
Total & & 75 & 100 \\
\hline
\end{tabular}

Source: Results of Statistical Analysis through the SPSS Program. 20

From the results of the calculation of the data above, it can be seen based on the respondents' answers that the level of intention to repeat order partners of RPK Perm BULOG Southeast Sulawesi Regional Office is classified as "High" with a frequency of 43 respondents and a percentage rate of $57.5 \%$. This can also be proven by finding the number of means and standard deviation as follows.

Table 5.

Summary of Analysis Results of Average and Standard Deviation of Repeat Order Variables

Ytotal

\begin{tabular}{|l|r|r|}
\hline & N Valid & 75 \\
Mean & & Missing \\
& & 40.59
\end{tabular}


Anggraeni Damayanti Salam, et. All: Calling Customer Role of Intent Repeat Order 115

\begin{tabular}{|l|r|} 
Std. Error of Mean & .614 \\
Median & 40.00 \\
Std. Deviation & 5.315 \\
\hline
\end{tabular}

Source: Results of Statistical Analysis through the SPSS Program. 20

Based on the results of the analysis of the average and standard deviation of the repeat order variable in the table above, it shows that the mean (mean) score of the respondents' answers is 40.59 and when consulted with the standard deviation based on the description table of the calling customer variables above, the average 40.59 are in the "High" category interval, while the standard deviation is 5.31. The data was obtained from the results of data processing through the SPSS 20 program.

\section{CONCLUSION}

Description of Calling Customer (X) at Perm BULOG, Southeast Sulawesi Regional Office, Kendari City, is in the Satisfactory category. in this case in terms of the Calling Customer variable. The highest indicator in the customer calling variable $(x)$ is the Service indicator. Overview of partner's Repeat Order (Y) at Perm BULOG, Southeast Sulawesi Regional Office, Kendari City, is in the High category in terms of the Repeat Order variable. The highest indicator in variable repeat orders $(\mathrm{y})$ is the indicator of interest. So it can be concluded that there is a significant relationship and a positive influence between the role of customer calling on the intention to repeat orders for our food house partners perm BULOG Southeast Sulawesi Regional Office.

\section{REFERENCE}

Deng, Y., Staelin, R., Wang, W., \& Boulding, W. (2018). Consumer sophistication, word-of-mouth and "False" promotions. Journal of Economic Behavior \& Organization, 152, 98-123. https://doi.org/https://doi.org/10.1016/j.jebo.2018.05.011

Guo, J., Wang, X., \& Wu, Y. (2020). Positive emotion bias: Role of emotional content from online customer reviews in purchase decisions. Journal of Retailing and Consumer Services, 52, 101891. https://doi.org/https://doi.org/10.1016/j.jretconser.2019.101891

Henni Zainal, U. I. T., Parinsi, W. K., Indonesia, S. P., Hasan, M., \& Makassar, U. N. (2018). The Influence Of Strategic Assets And Market Orientation To The Performance Of Family Business In Makassar City, Indonesia. 17(6), 1-9.

Herdiyanti, A., Adityaputri, A. N., \& Astuti, H. M. (2017). Understanding the Quality Gap of Information Technology Services from the Perspective of Service Provider and Consumer. Procedia Computer Science, 124, 601-607. https://doi.org/https://doi.org/10.1016/j.procs.2017.12.195

Kamrath, C., Bidkar, S., \& Bröring, S. (2019). Is food involvement in purchasing decisions always low? A consumer study from Germany. PharmaNutrition, 9, 100157. https://doi.org/https://doi.org/10.1016/j.phanu.2019.100157

Lv, Z., Jin, Y., \& Huang, J. (2018). How do sellers use live chat to influence consumer purchase decision in China? Electronic Commerce Research and Applications, 28, 102-113. https://doi.org/https://doi.org/10.1016/j.elerap.2018.01.003

Peter, J. P., Olson, J. C., \& Grunert, K. G. (1999). Consumer behaviour and marketing strategy. McGraw-hill London.

Purba, R. (2012). Measuring Consumer Perceptions Through Factor Analysis”. The Asian.

Purnasari, H., \& Yuliando, H. (2015). How Relationship Quality on Customer Commitment Influences Positive e-WOM. Agriculture and Agricultural Science Procedia, 3, 149-153. https://doi.org/https://doi.org/10.1016/j.aaspro.2015.01.029

Safarnia, H., Akbari, Z., \& Abbasi, A. (2011). Review of market orientation \& competitive advantage in the industrial estates companies (Kerman, Iran): appraisal of model by Amos Graphics. World 
116 |Jurnal Office: Jurnal Pemikiran Ilmiah dan Pendidikan Administrasi Perkantoran

Vol. 6 No. 2, July - December 2020. Page 111-116

Journal of Social Sciences, 1(5), 132-150.

Sugiyono. (2017). Pendekatan Kuantitatif, Kualitatif, Kombinasi, R\&D dan Penelitian Evaluasi. Alfa Beta.

Vijande, M. L. S., Sanzo Pérez, M. J., Álvarez González, L. I., \& Casielles, R. V. (2005). Effects of market orientation on business strategic behaviour. Journal of Strategic Marketing, 13(1), 17 42.

Zhu, D. H., Chang, Y. P., \& Luo, J. J. (2016). Understanding the influence of C2C communication on purchase decision in online communities from a perspective of information adoption model. Telematics and Informatics, 33(1), 8-16. 